\title{
Nursing Intervention Classifications (NIC) validated for patients at risk of pressure ulcers ${ }^{1}$
}

\author{
Taline Bavaresco ${ }^{2}$ \\ Amália de Fátima Lucena ${ }^{3}$
}

Objective: to validate the Nursing Intervention Classifications (NIC) for the diagnosis 'Risk of Impaired Skin Integrity' in patients at risk of pressure ulcers (PU). Method: the sample comprised 16 expert nurses. The data was collected with an instrument about the interventions and their definitions were scored on a Likert scale by the experts. The data was analyzed statistically, using the calculation of weighted averages (WA). The study was approved by the Research Ethics Committee (56/2010). Results: nine interventions were validated as 'priority' (WA $\geq 0.80)$, among them Prevention of PU (MP=0.92); 22 as 'suggested' (WA >0.50 and <0.80) and 20 were discarded (WA $\leq 0.50$ ). Conclusions: the prevention of $\mathrm{PU}$ results from the implementation of specific interventions related to the risk factors for development of the lesion, with implications for nursing practice, teaching and research.

Descriptors: Nursing Process; Pressure Ulcer; Nursing Care; Validation Studies.

\footnotetext{
${ }^{1}$ Paper extrated from Master's Dissertation "Validação de intervenções de enfermagem para o diagnóstico Risco de Integridade da Pele Prejudicada para pacientes em risco de Úlcera por Pressão", presented to Universidade Federal do Rio Grande do Sul, Brazil. Supported by Fundo de Incentivo à Pesquisa e Eventos (FIPE) do Hospital de Clínicas de Porto Alegre (HCPA), Brazil.

2 MSc, Professor, Universidade de Caxias do Sul, Brazil.

${ }^{3}$ PhD, Adjunct Professor, Escola de Enfermagem, Universidade Federal do Rio Grande do Sul, Brazil.
} 


\section{Intervenções da Classificação de Enfermagem NIC validadas para pacientes em risco de úlcera por pressão}

Objetivo: validar as intervenções da classificação de enfermagem NIC para o diagnóstico Risco de Integridade da Pele Prejudicada, em pacientes em risco de úlcera por pressão (UP). Método: a amostra foi composta por 16 enfermeiras experts. Os dados foram coletados em instrumento contendo a caracterização das participantes, além de uma tabela com as intervenções e a definição de cada uma delas, bem como uma escala Likert que foi pontuada pelas experts. Os dados foram analisados estatisticamente, utilizando-se cálculo de média ponderada (MP). O estudo foi aprovado em Comitê de Ética e Pesquisa (56/2010). Resultados: validaram-se nove intervenções como prioritárias ( $M P \geq 0,80)$, dentre elas prevenção de UP $(M P=0,92)$; 22 como sugeridas (MP>0,50 e $<0,80$ ) e 20 foram descartadas ( $M P \leq 0,50)$. Conclusões: a prevenção da UP perpassa pela implementação de intervenções específicas e relacionadas aos fatores de risco ao desenvolvimento da lesão, com implicações na prática, ensino e pesquisa de enfermagem.

Descritores: Processos de Enfermagem; Úlcera de Pressão; Cuidados de Enfermagem; Estudos de Validação.

\section{Intervenciones de la Clasificación de Enfermería NIC validadas para pacientes en riesgo de úlcera por presión}

Objetivo: validar las intervenciones de la clasificación de enfermería NIC para el diagnóstico Riesgo de Integridad de la Piel Perjudicada en pacientes en riesgo de úlcera por presión (UP). Método: la muestra fue compuesta por 16 enfermeras experts. Los datos colectados en instrumento con las intervenciones, su definición y una escala Likert puntuada por las experts. Los datos analizados estadísticamente, utilizándose cálculo de media ponderada (MP). Estudio aprobado en Comité de Ética e Investigación (56/2010). Resultados: se validaron nueve intervenciones como prioritarias ( $M P \geq 0,80$ ), entre ellas Prevención de UP $(M P=0,92)$; 22 como sugeridas (MP >0,50<0,80) y 20 fueron descartadas ( $M P \leq 0,50$ ). Conclusiones: la prevención de la UP, pasa a través de la implementación de intervenciones específicas y relacionadas a los factores de riesgo al desarrollo de la lesión, con implicaciones a la práctica, enseñanza e investigación de enfermería.

Descriptores: Procesos de Enfermería; Úlcera de Presión; Cuidados de Enfermería; Estudios de Validación.

\section{Introduction}

The method which guides the nurse's clinical judgment and decision-making is termed the Nursing Process (NP), comprising stages of investigation (data collection), nursing diagnosis (ND), planning, implementation of nursing interventions and evaluation of the results presented by the patient, family or community as a result of the specific nursing practices ${ }^{(1)}$.

In the stages referent to the diagnosis, the intervention and the result, standardized terms described by the classification systems may be used, which point to the common phenomena in and for clinical nursing practice. Currently, the systems for classification of language which are most known and used in the Brazilian context are the NANDA-International taxonomies (NANDA-I $^{(2)}$, the Nursing Interventions Classification $(\mathrm{NIC})^{(3)}$ and the Nursing Outcomes Classification NOC-(4). These classifications promote the systematic communication and documentation of nursing actions, in addition to other benefits related to clinical practice ${ }^{(3)}$.

The care settings where the NP and classification systems may be applied are diverse, so some specific cases need to be better explored. One such case is the scenario of preventing pressure ulcers (PU), which demand concern from nurses and have been the object of discussion, principally in the hospital setting. The incidence of PU, however, remains high and these lesions 
are an important cause of morbidity-mortality, affecting the patients' quality of life, as well as creating costs for the health services ${ }^{(5)}$.

A PU is a lesion of the skin and/or the underlying tissue, generally over a boney prominence, due to pressure which may be combined with shearing and/ or friction ${ }^{(5)}$. The following stand out among the risk factors which contribute to patients' exposure to the development of PU: deficit in mobility and/or sensitivity, friction and shearing, edema, humidity, advanced age, systemic illnesses, use of certain medications such as corticoids, anti-inflammatories and antibiotics, nutritional deficiency, neurological compromise and metabolic disorders ${ }^{(5)}$.

The early and regular risk stratification for the development of PU, which may be accomplished through the use of scales such as the Braden scale, supports the adoption of preventive measures for reducing the factors which predispose to tissue hypoperfusion, the optimizing of the individual's general and nutritional status, and the promotion of localized care to the skin ${ }^{(6)}$. This evaluation can also support the establishment of an accurate ND, which is a basis for the selection of nursing interventions for each patient, taking into account the anticipated results ${ }^{(3)}$.

Currently, the diagnosis (NANDA-I) which best translates the situation of vulnerability to $\mathrm{PU}$ is the 'Risk for Impaired Skin Integrity' (00047), found in Domain 11, Safety/protection, in class 2 of Physical injury. So that this ND may be identified with greater accuracy, NANDA-I recommends the use of a standardized risk evaluation instrument (2), such as, for example, the Braden Scale, which evaluates an individual's risk of PU. However, the ND in question is not specifically for determining the risk of $\mathrm{PU}$, but rather any risk to the skin's integrity.

Although the NIC presents various possibilities for interventions for this ND, there are no validation studies in the care setting for patients at risk of PU. A recent search in a database using the terms "nursing interventions classification and validation study" found 35 publications $^{(7)}$, of which four were Brazilian. None of these presented the PU as a clinical situation under study, which reinforces the purpose of the present investigation about nursing interventions for patients at risk of $\mathrm{PU}$, based on the linkages between NICNANDA-I. These linkages are defined as the relation or association between NANDA-I diagnoses and a NIC nursing intervention which aims to minimize or resolve the problem in question, in this case the $\mathrm{PU}^{(3)}$.
In the NIC's linkages with NANDA-I, 48 nursing interventions for the ND of Risk for Impaired Skin Integrity are presented, of which three are 'priority', 28 'suggested', and a further 17 'optional'(8). The 'priority' interventions are those most likely to resolve the problem. The 'suggested' interventions have a high probability of resolving the ND and the 'additional optional' interventions are those which apply only to some of the patients with the ND. In addition to these 48 interventions, in the book 'NOC and NIC linkages to NANDA-I', the existence was ascertained of other nursing interventions, for the ND of Risk for Impaired Skin Integrity ${ }^{(9)}$.

Thus, taking into account the chapter on linkages between NIC and NANDA-I and that proposed by the book NOC and NIC linkages to NANDA-I, 51 nursing interventions were found which were possible to apply to patients at the ND Risk for Impaired Skin Integrity. However, these had not yet been validated in the care setting for patients at risk of PU. Thus, considering the importance of extending knowledge about interventions for preventing PU and for improving the applicability of the NIC, the present study was carried out, with the aim of validating the content of the nursing interventions for the ND of Risk for Impaired Skin Integrity, for adult patients at risk of pressure ulcers, based on the linkage between NIC and NANDA-I.

\section{Method}

This is a content validation study, carried out between March 2010 and December 2011 in two Brazilian university hospitals, one in the South region of the country and one in the South-east. The sample was comprised of 16 expert nurses belonging to study and research groups in these two hospitals in the area of nursing care for the skin.

The inclusion criteria were: to participate of have participated in the study group on skin and wound care, for at least one year; to have clinical practice experience in skin care, specifically in the care of patients at risk of $\mathrm{PU}$; to know and/or use the nursing process and the nursing classification systems with standardized terminology (NANDA-I and NIC) and to use a protocol for the prevention and treatment of PU, with the Braden Scale administered as the risk predicting instrument for this health hazard.

Data collection was accomplished using an instrument constructed based on the linkages existing between NIC and NANDA-I and delivered by the 
researcher to the participants using an email created for the study. Prior to this, the researcher met with representatives of the groups which made up the sample, to present the study's objectives.

The data collection instrument contained data for characterizing the participants, as well as a table with six columns, in which the first showed the title and the definition of each of the 51 NIC interventions submitted for validation. The other columns contained a Likert scale of 1 to 5 points, in which the experts indicated a mark based on an evaluation of how much the content of each intervention was used for the ND Risk for Impaired Skin Integrity, in particular for patients at risk of PU. The expert nurses gave the scores in the following way: $1=$ not used; $2=$ used very little; $3=$ used to some degree; $4=$ considerably used and $5=$ highly used. Guidance on how to fill out and return the instrument was sent to the participants along with the instrument.

Data analysis was undertaken statistically, taking into account the marks given by the experts for each intervention ${ }^{(11)}$. The marks' weighted averages were calculated, with the following weights being

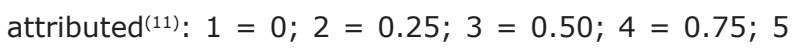
$=1$. This calculation defined the priority interventions, that is, those with a weighted average of $\geq 0.80$; the suggested interventions, which obtained averages of $>0.50$ and $<0.80$ and the discarded ones, whose averages were $\leq 0.50$.

The project was approved by the Research Commissions (56/2010) and by the Ethics Committees (110028) of the institutions involved, as it met all of the ethical principles for the investigation.

\section{Results}

The sample was comprised of 16 expert nurses, who had graduated on average 104.5 (14 - 320) months previously and who had participated in study groups on skin and wounds for an average of 33.5 (12 - 144) months. Seven $(43.75 \%)$ of the experts held the title of specialist, followed by $4(25 \%)$ with doctorates. The predominant area of professional activity was clinical care, with 13 (81.25\%) nurses.

Regarding the experts' participation in events on the issue of nursing processes, $10(62.5 \%)$ of them had undertaken up to 10 hours of activity, while on the subject of pressure ulcers, $6(37.5 \%)$ had undertaken over 40 hours of activities. Seven (43.75\%) experts had participated in events on NP as much as events on PU. It was also identified that $7(43.75 \%)$ nurses had published up to 10 articles, $3(18.75 \%)$ had authored at least one chapter and/or book on the issue in question, and that $5(31.25 \%)$ had published up to 10 works in the proceedings of scientific congresses.

The results of the validation of the content of the 51 NIC nursing interventions for the ND Risk for Impaired Skin Integrity in patients at risk of PU were as follows: $9(17.6 \%)$ interventions were validated as 'priority', with a weighted average of $\geq 0.80 ; 22$ (43.1\%) were validated as 'suggested', with a weighted average of $>0.50$ and $<0.80$ and 20 (39.3\%) were discarded, as they presented a weighted average of $\leq 0.50$. The nine nursing interventions validated as priority are presented in Table 1.

Table 1 - Nursing interventions validated as priority for the ND Risk for Impaired Skin Integrity in the setting of care for patients at risk of PU. Porto Alegre, Rio Grande do Sul, Brazil, 2012

\begin{tabular}{|c|c|}
\hline Interventions validated as 'priority' $(n=51)$ & Weighted average \\
\hline Pressure ulcer prevention (3540)* & 0.92 \\
\hline Pressure management $(3500)^{*}$ & 0.89 \\
\hline Skin surveillance $(3590)^{*}$ & 0.89 \\
\hline Bathing $(1610)^{\dagger}$ & 0.87 \\
\hline Skin care: topical treatments $(3584) \ddagger$ & 0.86 \\
\hline Vital signs monitoring $(6680)^{\dagger}$ & 0.84 \\
\hline Urinary elimination management $(0610) \S$ & 0.82 \\
\hline Positioning $(0840)^{\ddagger}$ & 0.80 \\
\hline Nutrition management $(1120)^{\dagger}$ & 0.80 \\
\hline Total & $9(17.6 \%)$ \\
\hline
\end{tabular}

* Nursing interventions also described in the NIC as priority by the linkage between NIC and NANDA-I.

+ Nursing interventions described in the NIC as 'additional optional' for the linkage NIC and NANDA-I.

₹ Nursing interventions described in the NIC as 'suggested' by the linkage between NIC and NANDA-I.

$\S$ Nursing intervention described as 'additional optional' in the book "NOC and NIC linkages to NANDA-I".

The 22 interventions validated as 'suggested', with a weighted average $>0.50$ and $<0.80$, are presented in Table 2.

Table 2 - Nursing interventions validated as 'suggested' for the ND Risk for Impaired Skin Integrity in the setting of care for patients at risk of PU. Porto Alegre, Rio Grande do Sul, RS, Brazil, 2012

\begin{tabular}{lc}
\hline Interventions validated as 'suggested' (n=51) & Weighted average \\
\hline Nutrition management (1100) & 0.78 \\
Supervision $(6650)^{*}$ & 0.77 \\
Bed rest care $(0740)$ & 0.77
\end{tabular}


Table 2 - (continuation)

\begin{tabular}{|c|c|}
\hline Interventions validated as 'suggested' $(n=51)$ & Weighted average \\
\hline Wound care $(3660)^{*}$ & 0.77 \\
\hline Infection protection $(6550)^{*}$ & 0.75 \\
\hline Bowel incontinence care $(0410)$ & 0.75 \\
\hline Infection control $(6540)^{*}$ & 0.75 \\
\hline Splinting $(0910)^{*}$ & 0.70 \\
\hline $\begin{array}{l}\text { Total Parenteral Nutrition (TPN) administration } \\
(1200)\end{array}$ & 0.70 \\
\hline Exercise therapy: ambulation $(0221)^{*}$ & 0.69 \\
\hline Circulatory precautions $(4070)^{\star}$ & 0.69 \\
\hline Positioning: wheelchair (0846) & 0.69 \\
\hline Bleeding precautions (4010) & 0.67 \\
\hline Prosthesis care (1780) & 0.66 \\
\hline Traction/immobilization care $(0940)^{*}$ & 0.64 \\
\hline Perineal care $(1750)$ & 0.62 \\
\hline Diarrhea management (0460) & 0.62 \\
\hline Self-care assistance: bathing / hygiene (1801) & 0.62 \\
\hline Positioning: Intraoperative $(0842)^{*}$ & 0.59 \\
\hline Self-care assistance: toileting (1804) & 0.55 \\
\hline Ostomy care $(0480)^{*}$ & 0.53 \\
\hline Incision site care $(3440)^{*}$ & 0.53 \\
\hline Total & $22(43.1 \%)$ \\
\hline
\end{tabular}

*Nursing interventions also described in the NIC as 'suggested' by the linkage NIC-NANDA-I.

Twenty interventions were discarded in the study, with a weighted average of $\leq 0.50$ (Table 3 ).

Table 3 - Nursing interventions discarded for the ND Risk for Impaired Skin Integrity in the setting of care for patients at risk of PU. Porto Alegre/Rio Grande do Sul, RS, Brazil, 2012

\begin{tabular}{lc}
\hline \multicolumn{1}{c}{ Discarded Interventions $(\mathbf{n = 5 1 )}$} & Weighted average \\
\hline Lower extremity monitoring (3480) & 0.50 \\
Cast care: maintenance (0762) & 0.50 \\
Fluid/Electrolyte management (2080) & 0.50 \\
Cast care: wet (0764) & 0.48 \\
Foot care (1660) & 0.47 \\
Electrolyte management (2000) & 0.47 \\
Medication administration: skin (2316) & 0.47 \\
Exercise promotion (0200) & 0.45 \\
Amputation care (3420) & 0.45 \\
Exercise therapy: joint mobility (0224) & 0.44 \\
Medication management (2380) & 0.44 \\
Teaching: foot care (5603) & 0.42 \\
Exercise promotion: strength training (0201) & 0.37 \\
Exercise therapy: muscle control (0226) & 0.36 \\
Massage (1480) & 0.36 \\
Exercise promotion: stretching (0202) & 0.34 \\
Exercise therapy: balance (0222) & 0.31 \\
Nail care (1680) & 0.31 \\
Latex precautions (6570) & 0.23 \\
Rectal prolapse management (0490) & 0.23 \\
\hline
\end{tabular}

\section{Discussion}

The selection of the expert nurses was guided by the search for professionals with experience in clinical care practice, in two university hospitals recognized in Brazil for their excellence in health care, teaching and research. For this reason, the participants had a significant number of scientific publications and courses taken on NP and on PU, which demonstrates their technical-scientific knowledge and strengthens the reliability of the results of this content validation study.

Nine NIC nursing interventions for the ND Risk for Impaired Skin Integrity in patients at risk of PU, among the 51 studied, were validated as 'priority'. Among these are the three (Pressure ulcer prevention, Pressure management, and Skin surveillance) which are highlighted by the NIC-NANDA-I linkage as priority for the ND under study. The importance of this data is corroborated by the literature, which demonstrates the need for these interventions to help in the early minimization of risk factors for $\mathrm{PU}$, with emphasis on controlling sources of pressure and on constant supervision of the $\operatorname{skin}^{(12-14)}$.

The interventions Skin Care: topical treatments and Positioning, validated in the present study as 'priority', are presented as 'suggested' in the NIC-NANDA-I linkage. It is emphasized that the use of products applied topically can alter or maintain the integrity of the skin and that currently there are various products for this, aimed at avoiding the development of PU(15-16). They require, however, constant assessment on the part of nursing (17-18).

PU can originate from inadequate positioning of the patient and/or remaining in the same position for a long time, which causes pressure on particular areas of the body. This requires intervention in the form of (re-) positioning one or more areas of the body in contact with a hard surface, such as the mattress and/or chair, as the frequent mobilization of the patient is a means of avoiding, reducing and/or controlling the occurrence of $\mathrm{PU}^{(16)}$. The changes in the patient's position, whether in bed or the chair, and the use of equipment adapted to relieve pressure, are essential in the prevention of $\mathrm{PU}$, as they help interrupt the process of local cellular hypoxia, which interferes directly in the appearance of the lesion ${ }^{(17-18)}$.

The interventions Bathing, Vital signs monitoring and Nutrition management were also validated as 'priority' in the present study. They are, however, considered additional optional interventions in the NIC-NANDA-I 
linkage for the ND Risk for Impaired Skin Integrity. The intervention Bathing includes skin hygiene, which must be clean, without moisture, and sufficiently hydrated to reduce the risk of PU and invasion of pathogens(18-19). In addition to this, in the case of bathing, the nurses can supervise the condition of skin integrity and provide relief from the sources of pressure, stimulating the circulation and repositioning the patient.

The importance of Vital signs monitoring in the evaluation of the circulatory condition and the skin temperature is also recognized, as it can support the nurse in making a risk diagnosis such as the one studied. Similarly, the evaluation of these patients' nutritional status is important, as it determines the need for the validated intervention of Nutrition management, to maintain the organism with an adequate nutritional intake and thus facilitate its capacity to maintain skin integrity, in addition to promoting its regeneration and the process of healing ${ }^{(16,20)}$.

The intervention Urinary elimination management, presented as an additional optional intervention for the ND Risk for Impaired Skin Integrity in the book 'NOC and NIC linkages to NANDA-I'(9), was also validated as 'priority'. It is known that one of the determinants for PU is skin moisture, a condition which makes it more fragile and susceptible to friction and maceration. Moisture, whether from products or from physiological secretions or fluids, causes softening and maceration of the skin, with a reduction in its tensile strength, rendering it weaker to compression, friction and shear, in addition to fostering an increase in the growth of micro-organisms which impair its integrity ${ }^{(20)}$.

Accordingly, all of the interventions validated as priority are applicable to the clinical conditions which interfere in maintaining skin integrity, and may minimize the risk of PU. The differences found in the study in relation to the level of linkage between the NIC interventions and the NANDA-I NDs are explained, considering that the NIC indicates interventions associated with NDs, while emphasizing that these are not prescriptive but depend on the nurse's judgment of the condition presented by the individual(3). Added to this, the validation studies seek to identify, in a set of interventions, those which are most suitable for the care of patients in specific clinical situations, such as, for example, that of being at risk of a PU ${ }^{(21)}$. In the present study, it was interventions for the ND Risk for Impaired Skin Integrity in the setting of care for patients at risk of PU that were validated, rather than interventions for other types of risk involving skin lesions.
This study's results may also be related to the six subscales which make up the Braden scale, which evaluate sensory perception, skin moisture, activity, mobility, nutritional intake, friction and shear. The changes, when identified, indicate the need for interventions such as those validated, as they prevent and/or treat the situations which foster the development of $\mathrm{PU}^{(12-13,20)}$

The number of nursing interventions validated as 'priority' in the care of patients at risk of PU (nine) was greater than that presented at this level in the chapter on linkages of NIC interventions with the ND of Risk for Impaired Skin Integrity. These results strengthen the specificity of care for this clinical situation, which - on its own - indicates the need for a specific ND which could be termed Risk of Pressure Ulcer ${ }^{(22)}$.

In relation to the $22(43.1 \%)$ interventions validated as 'suggested', 11 (50\%) of them are also considered such by the NIC in its chapter on linkages. This set of interventions corroborates the nurses' concerns in relation to the control of nutrition, care of wounds, the importance of assistance with self-care, and protection against and control of infection, which are contributing factors in the appearance of $\mathrm{PU}^{(23)}$.

Twenty $(39.3 \%)$ nursing interventions of the 51 submitted to the study were discarded, from which one may infer that it happened because of the specific characteristics of the type of patient under consideration, at risk of PU, and not because of other factors which could lead to the establishment of the ND of Risk for Impaired Skin Integrity. This idea is backed up by the fact that some of the discarded interventions refer to exercise therapy, amputation care, joint mobility, and to the feet and the nails, and are applicable to other care settings. It is also possible that some of them may be used in the care of patients at risk of PU, although on a smaller scale, as - as has already been noted - rather as the NIC does not present a prescriptive character for its interventions, neither does this study.

It is worth emphasizing one more time that the ND of Risk for Impaired Skin Integrity is broad and covers other situations of vulnerability of the skin integrity, raising doubts about its accurate applicability in specified situations such as that of risk of PU. Thus, the results of the validation of the NIC interventions for this ND, taking into account the specificity of the care for the patient at risk of PU, may also help in establishing the risk of the same with greater discernment, as well as helping in its prevention and treatment ${ }^{(24)}$. 
Thus, it is understood that the study's results advance knowledge of the NANDA-I and NIC classifications - principally of the latter, which present interventions which foster communication, the recording and the implementation of continuous and systematic nursing actions.

\section{Conclusions}

It is concluded that, of the 51 interventions proposed by the NIC for the ND of Risk for Impaired Skin Integrity, based on the NIC-NANDA-I linkage, nine may be considered as priority for adult patients at risk of pressure ulcer, these being: Pressure ulcer prevention, Pressure management, Skin surveillance, Bathing, Skin care: topical treatments, Vital signs monitoring, Urinary elimination management, Positioning and Nutrition management. These interventions were considered applicable to the prevention of PU, and may be used depending on the clinical situation evidenced and on the skills and knowledge of the nursing professionals who provide the continuous care to the patients, intervening in the risk factors for developing PU.

It was also observed that the use of instruments for predicting risk, such as the Braden scale, is important in guiding the ND, which is the basis for the nurse's action plan, to obtain positive results in preventing PU. As a limiting factor for the study, one may cite the low number of similar publications, to help in the comparison and discussion of the results obtained.

This research's implications are geared to the advance of knowledge in nursing care practice, as it validated priority interventions for the care of patients at risk of PU. It also has positive implications for teaching, as its results may facilitate an approximation between theory and practice. Further, it promotes the students' and health professionals' decision-making and clinical reasoning, which are skills fundamental to the application of the Braden scale. In a similar way, it has implications for nursing research, as based on these results, other studies may be boosted, such as those involving clinical validation of the interventions, and the development of new NDs.

\section{Acknowledgements}

The authors would like to thank Priscila Eugênio Fortes, a nursing student and scientific initiation scholarship student, for her collaboration in presenting part of the study at an international scientific event.

\section{References}

1. Almeida MA, Lucena AF. O processo de enfermagem e as classificações NANDA-I, NIC e NOC. In: Almeida $M A$, Lucena $A F$, Franzen $E$, Laurent MC. Processo de Enfermagem na Prática Clínica: estudos clínicos realizados no Hospital de Clínicas de Porto Alegre. Porto Alegre: Artmed; 2011. p. 23-40.

2. NANDA - International. Nursing diagnoses: definitions \& classification 2012-2014. Philadelphia: WileyBlackwell; 2012. 568 p.

3. Bulechek GM, Butcher HK, Dochterman JM. Classificação das intervenções de enfermagem - NIC. $5^{a}$ ed. Rio de Janeiro: Elsevier; 2010. 944 p.

4. Moorhead S, Johnson M, Maas M. Classificação dos resultados de enfermagem - NOC $4^{\mathrm{a} e d .}$ Rio de Janeiro: Elsevier; 2010. 936 p.

5. National Pressure Ulcer Advisory Panel (NPUAP). [Internet]. Washington (EUA). [acesso 10 out 2011]. Disponível em: http://www.npuap.org.

6. Magnan MA, Maklebust J. Braden Scale risk assessments and pressure ulcer prevention planning: what's the connection? J Wound Ostomy Continece Nurs. 2009;36(6):622-34.

7. Gopubmed. [Internet]. 2011 [acesso 28 nov 2011]. Disponível em: http://www.gopubmed.com.

8. Dochterman JM, Bulechek GM. Classificação das intervenções de enfermagem (NIC). $4^{a}$ ed. Porto Alegre: Artmed; 2008. 988 p.

9. Johnson M, Bulechek G, Butcher H, Dochterman JM, Maas M. Ligações entre: NANDA, NOC e NIC: Diagnósticos, resultados e intervenções de enfermagem. 2. ed. Porto Alegre: Artmed; 2009. 704 p.

10. Galdeano LE, Rossi LA. Validação de conteúdo diagnóstico: critérios para seleção de expertos. Ciência, Cuidado e Saúde. 2006;5(1):60-6.

11. Fehring R. Methods to validate nursing diagnosis. Heart \& Lung: J Acute Crit Care. 1987;16(6):625-9.

12. Bavaresco $T$, Medeiros RH, Lucena AF. Implantação da Escala de Braden em uma Unidade de Terapia Intensiva de um hospital universitário. Rev Gaúcha Enferm. 2011;32(4):703-10.

13. Lucena $A F$, Santos $C T$, Pereira AGS, Almeida MA, Dias VLM, Friedrich MA. Perfil clínico e diagnósticos de enfermagem de pacientes em risco para úlcera por pressão. Rev. Latino-Am. Enfermagem. [periódico na Internet]. 2011; [acesso 6 julho 2012]; 19(3):[08 telas]. Disponível em: http://www.scielo.br/pdf/rlae/ v19n3/pt_11.pdf 
14. Menegon DB, Pereira AG, Santos CT, Heckler S. Diagnósticos de enfermagem com base em sinais $\mathrm{e}$ sintomas do Sistema Tegumentar. In: Silva ERR da, Lucena AF. Diagnósticos de Enfermagem com base em sinais e sintomas. Porto Alegre: Artmed; 2010. p. 259-82.

15. Medeiros ABF, Lopes $C H A F$, Jorge MSB. Análise da prevenção e tratamento das úlceras por pressão propostas por enfermeiros. Rev EsC Enferm USP. 2009;43(11):223-8.

16. Paiva LC. Úlcera de pressão em pacientes internados em um hospital universitário em Natal/RN: condições predisponentes e fatores de risco [dissertação de mestrado]. Natal (RN): Universidade Federal do Rio Grande do Norte; 2008. 99 p.

17. Miyazaki MY, Caliri MHL, Santos CB. Conhecimento dos profissionais de enfermagem sobre prevenção da úlcera por pressão. Rev. Latino-Am. Enfermagem. [periódico na Internet]. 2010; [acesso 6 jan 2011]; 18(6):[10 telas]. Disponível em: http://www.scielo.br/ pdf/rlae/v18n6/pt_22.pdf

18. Goulart FM, Ferreira JA, Santos KAA, Morais VM, Freitas Filho GA. Prevenção de úlcera por pressão em pacientes acamados: uma revisão da literatura. Rev Objetiva. 2008;4:85-97.

19. Baumgarten M, Margolis D, Orwiq D, Hawkes W, Rich $S$, Langenberg $P$, et al. Use of Pressure-Redistributing Support Surfaces Among Elderly Hip Fracture Patients Across the Continuum of Care: Adherence to Pressure Ulcer Prevention Guidelines. Gerontologist. 2010;50(2):253-62.

20. Serpa LF, Santos VLCG, Campanili TCGF, Queiroz M. Predictive Validity of the Braden Scale for Pressure Ulcer Risk in Critical Care Patients. Rev. Latino-Am. Enfermagem. 2011;19(1):50-7.

21. Crossetti MGO, Antunes GSM, Tanccini T. Validação de diagnósticos, intervenções e resultados de enfermagem. In: Almeida MA, Lucena AF, Franzen E, Laurent MCR. Processo de enfermagem na prática clínica. Porto Alegre: Artmed; 2011. p. 89-99.

22. Santos CT, Lucena AF, Almeida MA, Oliveira MC. Risco para úlcera por pressão: um novo diagnóstico de enfermagem. In: Almeida MA, organizadora. 6. Simpósio do Processo de Enfermagem do Hospital de Clínicas de Porto Alegre; 25-26 junho 2012; Porto Alegre: HCPA; 2012. p. 53.
23. Souza AC, Pereira KC, Gama FN. O processo do cuidar: profissionais de enfermagem na prevenção e tratamento da úlcera de pressão. Rev EnfermIntegrada. 2010;1(3):369-80.

24. Rogenski NMB, Kurcgant P. Incidência de úlceras por pressão após a implementação de um protocolo de prevenção. Rev. Latino-Am. Enfermagem. [periódico na Internet]. 2012;[acesso 10 jun 2012]; 20(2):[07 telas]. Disponível em: http://www.scielo.br/scielo. php?pid=S0104-11692012000200016\&script =sci_ arttext\&tlng $=p t$ 